volume should be of value to the postgraduate student in his approach to clinical neurological problems. The usefulness is enhanced by a good bibliography.

\section{A POCKET MEDICINE}

By G. E. Beaumont, M.A., D.M., F.R.C.P., D.P.H. 3rd Edition. Pp. viii + 210. London: J. \& A Churchill, Ltd. I954. Ios. 6d.

Dr. G. E. Beaumont, who is the author of a wellknown standard text book of medicine, has here endeavoured to compress the whole of medicine into just over 200 very small pages. This is of course an impossible task and for the fact that he has failed the author is hardly to be blamed unless indeed he is to be blamed for attempting the task at all ! As would be expected of anything written by Dr. Beaumont, the information is accurate, but the material is so compressed, and so much is omitted, that it is very difficult to imagine anyone who will benefit by reading the book. Perhaps, however, it may act as a sedative for overwrought students in their last few days before the final examination in medicine.

\section{AN INTRODUCTION TO PHYSICAL} METHODS OF TREATMEN I IN PSYCHIATRY

By William Sargent, M.A., M.B., F.R.C.P., and

Eliot Slater, M.A., M.D., F.R.C.P. 3 rd

Edition. Pp. xix +351 , illustrated. Edinburgh:

E. \& S. Livingstone, Ltd. 1954. 20 .

This new edition of what has become an accepted textbook on the subject maintains the high standard set by its predecessors. During the last decade, the rapid introduction of physical methods of treatment into psychiatry has proved that the change in nomenclature accorded to the asylum is no mere Victorian euphemizing. Mental illness requires the same clinical approach as any other disease, and in the last analysis it may yet be shown to be merely one end of a psycho-somatic continuum. These treatments are largely empirical; some of the more successful, in fact, were founded upon hypotheses which later knowledge has invalidated. Theory is still very inadequately developed, as the authors admit, but some of the theoretical implications would not come amiss to the young clinician in psychiatry, to whom, inter alia, this book is addressed. 'Meduna's studies of neural feedback and threshold elevation, for example, while still requiring further experimental validation, do help to make carbon dioxide abreaction a little less puzzling to the tyro, and provide an incentive for the careful patient-selection which the authors so rightly emphasize.

It is fair to state, however, that this work is produced essentially as a practical manual, and as such is eminently successful. The text has been completely revised, and users of the earlier work will appreciate the rewritten and fully comprehensive chapter on psycho-surgery. The G.P. will find this book invaluable as a guide to suitable psychiatric out-patient treatment, while to the potential diplomat in psychological medicine it is very much a sine qua non.

\section{A CIBA FOUNDATION SYMPOSIUM: LEUKAEMIA RESEARCH}

Edited by Dr. G. E. W. Wolstenholme, O.B.E., M.A., M.B., B.Ch., and Miss M. P. CAMERoN, M.A., A.B.L.S. Pp. xiv +297 , with 56 illustrations. London: J. \& A. Churchill. 1954. 3os.

In November 1953 a symposium on the present status of research in leukaemia was held at the Ciba Foundation in London under the chairmanship of Professor L. J. Witts. The symposium began with a paper by Engelbreth-Holm who reviewed in a very stimulating way some points in leukaemia research which he felt deserved further investigation. Dr. Burchenal then described the effect of different agents on human and mouse leukaemia, and Dr. Israels continued the discussion of the analogy of human and experimental leukaemias. After further papers on animal leukaemias, particularly on transmissible fowl and mouse leukaemias, Drs. Lacassagne and Bessis contributed an interesting paper on electron and phase microscopy of the leucaemic cell. Other papers were read on the action of ionising irradiation in causing leukaemi and on the modification of irradiation injury by various methods. Finally, as would be expected, a number of papers were read on the subject of the newer drugs used in the treatment of leukaemia, especially myleran B.E.P. and Demecholin. The papers were followed by informal discussions. This book consists of a verbatim report of the symposium. It makes extremely interesting, if 3 somewhat depressing, reading; interesting because $\bar{P}$ of the evidence of the vast amount of work being done in the field of leukaemia research, but depressing because of the uniform failure of any 3 form of treatment to cure the disease.

\section{CHEMOTHERAPY OF INFECTIONS}

By H. O. J. Collier, B.A., Ph.D. Pp. xvi +248 , 은 with 53 illustrations. London: Chapman \& Hall, Ltd. r954. I8s.

This little book is one of the "Frontiers of Science' series, a series which attempts to fill the $O$ gap between very elementary introductory books $N$ and specialist text books. The author of this N volume which is entitled "Chemotherapy of $\omega$ Infections 'is chief pharmacist to Allen \& Hanbury's Ltd. He has clearly a very considerable knowledge $\bullet$ of his subject. In his opening chapters he deals $\Phi$ with many of the problems of chemotherapy and $\stackrel{\mathcal{P}}{+}$ then considers in detail most of the more commonly $T$ used antibiotics. He has also included sections $\stackrel{\circ}{\circ}$ on the sulphonamides, and the chemotherapy of 
malaria, tuberculosis and leprosy, leishmaniasis, trypanosomiasis and amoebiasis. There is a great deal of information about chemotherapy crowded into this small book, much of it not readily accessible elsewhere, and although it will almost certainly prove far too detailed for the ordinary lay reader, there must be many medical men who will derive great pleasure and profit from reading it.

\section{RECENT ADVANCES IN CHEMOTHERAPY}

\section{Vol. III-Antibiotics}

By F. C. O. Valentine, F.R.C.P. and R. A. Shooter, M.A., M.D. 3rd Edition. Pp. viii + 292, with 7 illustrations. London: J. \& A. Churchill, Ltd. 1954. 27 s 6 d.

This volume is one of those forming the third edition of the late Dr. G. M. Findlay's book, of which the previous edition appeared in 1939 . While incorporating much of his material, the authors have therefore written an entirely new book dealing with an era of therapeutics that hardly seemed remotely possible 15 years ago. Fewer than 30 of the several hundred references are to papers published more than ten years ago. On the other hand, the very large number listed that appeared in 1953 testifies to the efforts made by the authors to summarize the immense and rapidly growing literature. This is an admirable book concise and authoritative, giving chapter and verse for much advice on therapy that must occasionally be controversial when one treatment may be superseded by another almost before its validity can be firmly established. A reasonable balance is struck between the laboratory and the ward. Two suggestions might be worth following in the next edition-the whole subject of the prophylaxis of infections might be dealt with in a separate section, while there is a need for a really vigorous chapter entitled 'The Dangers and Complications of Antibiotic 'Therapy.'

\section{THE HAEMOLYTIC ANAEMIAS, CONGENITAL AND ACQUIRED}

By J. V. DAcie, M.D., M.R.C.P. Pp. $x+525$, with 98 illustrations. London: J. \& A. Churchill, Ltd. 1954. 50s.

This book on the haemolytic anaemias is a comprehensive review by a haematologist of international reputation who has made a special study of this subject over a period of many years. In addition to reviewing the world literature $\mathrm{Dr}$. Dacie has drawn extensively on his own clinical material and has included numerous case histories. The book opens with a chapter on the general features of abnormal haemolysis and the methods used in investigation. Thereafter follow detailed accounts of the different haemolytic anaemias. The last chapter describes in detail the techniques used in the investigation of these conditions. Altogether this is a most satisfying book that should undoubtedly be in the hands of every clinical pathologist, and indeed, of anyone interested in diseases of the blood. The reviewer has found little to criticise. Indeed, the only comment he would like to make is that he would like to have seen more details of the newer methods of estimating erythrocyte survival time. Dr. Dacie has done a service to haematology by writing this very comprehensive review. The book is well produced and adequate $y$ illustrated.

\section{THE ROOTS OF CRIME}

Edited by the late Sir NoRwood EAST, M.D., F.R.C.P. Pp. ix + r8r. London: Butterworth $\&$ Co., Ltd. I 954 . 30 .

This is a fascinating volume of reminiscences, opinions and informative essays by six notable contributors who write of what they know without paying more than a passing glance (or none) at its nominal subject.

He who is at all prepared to have his interest stimulated in crime and its reduction, or in criminals and their treatment, or in the ways and language of psychologists and psychotherapists, or in the current topics of spivs and homosexuals can get the book with confidence. But he must not expect an exhaustive scientific analysis concentrating actually upon the causes of crime.

The production is excellent for general arrange ment and readability: a full list of references follows each chapter; there is a glossary and an index. Short of browsing over the book itself, the best way to judge the nature and quality of its contents is to note the names and qualifications of the individual contributors and the titles under which each writes :

I. 'Legal and Medical Advances in Criminology,' by the late Sir Norwood East, M.D., F.R.C.P., formerly Lecturer on Forensic Psychiatry, Institute of Psychiatry, Maudsley Hospital; formerly H.M. Commissioner of Prisons, Inspector of Retreats under the Inebriate Acts.

2. 'A Psychiatric Approach to the Off ender,' by Desmond Curran, M.B., F.R.C.P., D.P.M., Senior Psychiatrist to St. George's Hospital; Civil Consultant, Psychological Medicine, to the Royal Navy.

3. 'A Clinical Contribution,' by Peter Scott, M.A., M.D., D.P.M., Physician to the Maudsley Hospital; Psychiatrist to L.C.C. Remand Home, Visiting Psychiatrist to H.M. Prison, Brixton.

4. 'Remedial and Educational Psychotherapy During Penal Detention,' by John C. Mackwood, M.C., M.R.C.S., L.R.C.P., Psychotherapist to H.M. Prison, Wormwood Scrubs.

5. 'The Role of Probation in the Treatment of Offenders,' by W. Clifford, B.Sc.(Econ.), Head of Welfare Department, Cyprus; formerly Probation Officer, Surrey.

6. 'The Magistrate and the Psychiatrist,' by Frank J. Powell, Metropolitan Police Magistrate, Clerkenwell.

B.M. 